\title{
Ultrafine particle dispersion in the metropolitan area of Guadalajara, Mexico
}

\author{
Dispersión de partículas ultrafinas en el área metropolitana de Guadalajara, \\ México
}

PEÑA-GARCÍA, Laura †*, ROBLES-MURGUÍA, Celia, MACIEL-FLORES, Roberto and ROSASELGUERA, José

Universidad de Guadalajara. Centro Universitario de Ciencias Biológicas y Agropecuarias. Camino Ramón Padilla Sánchez 2100, Nextipac, 44600 Zapopan, Jal.

ID $1^{\text {st }}$ Author: Laura, Peña-García / ORC ID: 0000-0002-9008-133, Researcher ID Thomson: U-4752-2018, CVU CONACYT ID: 311129

ID $1^{\text {st }}$ Coauthor: Celia, Robles-Murguía / ORC ID: 0000-0001-6413-0478, CVU CONACYT ID: 81038

ID $2^{\text {nd }}$ Coauthor: Roberto, Maciel-Flores / ORC ID: 0000-0002-3540-860X

ID $3^{\text {rd }}$ Coauthor: José, Rosas-Elguera / CVU CONACYT ID: 10786

DOI: $10.35429 /$ EJB.2020.13.7.11.17

Received: July 09, 2020; Accepted: November 23, 2020

\section{Abstract}

Objectives: Dust, soil and leaf samples of Ficus benjamina were collected in the metropolitan area of Guadalajara (GMA) (Peña-García et al., 2017), allowing to identify the type of metallic particles, size, shape and spatial distribution. With the results obtained, the possible effects of metallic particles on human and plant health were discussed (Peña-García et al., 2019). Methodology: The sampling was in six municipalities of the GMA; Atomic absorption spectrophotometry analyses were carried out on leaves, which identified the presence of various elements that mostly exceeded the reference values. Through X-ray fluorescence, 23 elements were identified in soil, including Th and Ac in at least 14 sites. Using the scanning electron microscopy technique and elemental mapping analysis, coarse, fine and ultrafine metallic particles were identified in human bronchus and lung tissue, as well as fragments of cement, plastic, yeast and bacteria. The similarity between the metallic particles in the collected samples and those observed in lung tissue, warns of latent risks to the health of the GMA population. Contribution: The results obtained with the methodology used in this work allow us to glimpse the polluting potential in urban areas.

Urban dust, Ficus benjamina, Heavy metals

\section{Resumen}

Objectives: Se recolectaron muestras de polvo, suelo y hojas de Ficus benjamina en el área metropolitana de Guadalajara (AMG) (Peña-García et al., 2017), permitiendo identificar el tipo de partículas metálicas, tamaño, forma y distribución espacial. Con los resultados obtenidos se discutió sobre los posibles efectos de partículas metálicas en la salud humana (Peña-García et al., 2019). Methodology: El muestreo fue en seis municipios del AMG; se realizaron análisis de Espectrofotometría de absorción atómica en hojas con lo que se identificó la presencia de diversos elementos que en su mayoría superó los valores de referencia. Mediante fluorescencia de rayos X se identificaron 23 elementos en suelo, entre ellos Th y Ac en al menos 14 sitios. Con la técnica de microscopía electrónica de barrido y análisis por mapeo elemental, se identificaron partículas metálicas gruesas, finas y ultrafinas en bronquio y tejido pulmonar humano, así como fragmentos de cemento, plástico, levadura y bacterias. La similitud entre las partículas metálicas en las muestras recolectadas y las observadas en tejido pulmonar, advierte riesgos latentes en la salud de la población del AMG. Contribution: Los resultados obtenidos con la metodología empleada en este trabajo permiten vislumbrar el potencial contaminante en las zonas urbanas.

Polvo urbano, Ficus benjamina, Metales pesados

Citation: PEÑA-GARCÍA, Laura, ROBLES-MURGUÍA, Celia, MACIEL-FLORES, Roberto and ROSAS-ELGUERA, José. Ultrafine particle dispersion in the metropolitan area of Guadalajara, Mexico. ECORFAN Journal-Bolivia. 2020. 7-13: $11-17$

\footnotetext{
$\dagger$ Researcher contributing as first author.
} 


\section{Introduction}

In Latin America and Mexico, productive activities have impacted the quality of life of the population and the environment, as well as the heavy vehicular load and the low rainfall (Querol, 2008). One of the biotic elements that have been used to characterize atmospheric pollution in urban dust, soil, suspended particles, sediments and in some plant species (Tam et al., 1988; Aguilar et al., 2011). It is particularly interesting to note that vegetation can be used as a biological indicator of trace elements, coarse, fine and ultra-fine particles from polluted air.

These bio-indicators have a high sensitivity to environmental changes in living beings, allowing to evaluate air quality in a very viable, fast and economical way and, most importantly, they can distinguish accumulations of toxic and polluting substances in ecosystems. Magnetic susceptibility techniques (Aguilar et al., 2012), infrared (Sangi, et al., 2008), scanning electron microscopy (Tomašević et.al., 2005), X-ray fluorescence (Marguí et.al., 2009) and atomic absorption (Sawidis et.al., 1995), have been used to identify and quantify a wide variety of airborne particles deposited on plant leaves.

The present work was carried out in six municipalities of the metropolitan area of Guadalajara (MAG), the samples were collected on March 23, 2013, in which the atmospheric contamination produced by metallic particles deposited on the ground and leaves of Ficus benjamina from the Metropolitan Area of Guadalajara, Mexico (Peña-García et al., 2016). In addition, the possible adverse effects on human health and on vegetation as a consequence of the presence of these particles are presented.

The following variables were defined: a) the chemical composition of the particulate material deposited on Ficus benjamina leaves, b) the presence of heavy metals in the soil, c) the amount of dust deposited on sidewalks, c) particles in the lung tissue of cadaveric samples observed (Instituto Jalisciense de Ciencias Forenses) (Peña-García et al., 2019a).
The PM deposited in the soil and in the Ficus benjamina leaves from the air pollution in the AMG, are constituted by a wide variety of heavy metals of different morphologies and sizes that can affect human health and the photosynthetic process of this species of tree (Peña-García et al., 2016).

\section{Methodology}

For the analysis of the Ficus benjamina leaf samples, more than one technique was used in order to corroborate the presence of the identified elements. We start with SEM images and their respective elemental mapping analysis (Peña-García et al., 2016), by X-ray energy dispersive spectrometry (EDS) to know the morphological and chemical characteristics of the localized particles. Later atomic absorption spectroscopy to determine concentration of elements such as $\mathrm{Cu}, \mathrm{Cd}, \mathrm{Co}, \mathrm{Cr}, \mathrm{Ni}, \mathrm{Pb}$ and $\mathrm{Zn}$ (Peña-García et al., 2019c). The magnetic properties were also analysed, with which a spatial distribution map of the magnetic susceptibility of heavy metals was elaborated to determine the areas with the highest presence of pollutants (Peña et al., 2016; Peña García et al., 2019c).

For soil, the selected technique was XRF through a qualitative elemental chemical analysis of elements comprised between fluorine (F) and uranium (U) (Peña-García et al., 2019c).

With the urban dust samples, the geostatistical interpretation was made and the map with the representation of areas of the city with higher dust density on the sidewalks (Peña-García et al., 2016).

\section{Results}

Through SEM, it was possible to determine the sedimentation of dust on both sides of the Ficus benjamina leaves that were systematically observed in several of the samples, so it can be deduced that a significant amount of particulate matter (PM) is present floating in the atmosphere of the GMA and are preserved in the leaves of the trees (Peña-García et al., 2019c). Of the samples observed in one, 26 elements were present, three with 21 , three with 19 , one with 17 , one with 16 and two with 14 elements present, with different land uses and types of roads (Peña-García et al., 2018). 
Traces of heavy metals such as $\mathrm{Cd}$, Co, $\mathrm{Cu}, \mathrm{Pb}$ and $\mathrm{Zn}$ were also observed in samples from other sites analysed by atomic absorption spectroscopy. Few fine and ultra-fine particles with oval and spherical shape were observed in all cases, as well as large aggregates (PeñaGarcía et al., 2019b). Also, aggregates of metal particles of irregular shape and size $<1 \mu \mathrm{m}$ which predominated in the leaves collected in other urban areas of Mexico (Reyes et al., 2012) and a great variety of heavy metals of micrometric size have been reported in other countries (Tam et al., 1988).

The most abundant elements were $\mathrm{Cu}, \mathrm{Pb}$ and $\mathrm{Zn},(14.58-24.72 \mathrm{mg} / \mathrm{Kg})$ and in lower concentrations $\mathrm{Cd}, \mathrm{Cr}$, Co and $\mathrm{Ni}(3.46-5.93$ $\mathrm{mg} / \mathrm{Kg}$ ) (Peña-García et al., 2019c). The average concentration of all heavy metals (except $\mathrm{Zn}$ ) was higher than the value reported in the "reference plant" proposed by Market (1992). The concentration values for $\mathrm{Cd}, \mathrm{Co}, \mathrm{Pb}$ $\mathrm{Ni}, \mathrm{Cr}$ and $\mathrm{Cu}$ were 69, 26, 20, 3.9, 3.6 and 2.47 times higher than the reference values, respectively. The high concentrations can be attributed to the progressive accumulation of metals in the leaves over time (Peña García $e t$ al., 2019c).

Regarding the magnetic parameters, the samples were divided into categories, such as land use and type of road. The highest average values of mass magnetic susceptibility are given for industrial land use $\left(7.56 \mu \mathrm{m}^{3} \mathrm{~kg}^{-1}\right)$, mixed $\left(6.29 \mu \mathrm{m}^{3} \mathrm{~kg}^{-1}\right)$, and urban corridor $(6.46$ $\left.\mu \mathrm{m}^{3} \mathrm{~kg}^{-1}\right)$, as well as in roads of zones agricultural $(7.20 \mu \mathrm{m} 3 \mathrm{~kg}-1)$ primary (6.04 $\mu \mathrm{m} 3 \mathrm{~kg}-1)$ and secondary $(6.07 \mu \mathrm{m} 3 \mathrm{~kg}-1)$ routes. A significant difference was identified in the average values of the different categories for land use and roads for $\chi \mathrm{d} \%$ and MRIS. Regarding MRI0.7 $\mathrm{T}$ and $\chi$ both present an almost linear trend, which indicates the presence of carriers of the ferrimagnetic type, clustering patterns of sites are observed according to land use and type of road.

The values of low magnetic concentration belong to a group of samples that are associated with: a) categories of land use of green areas, one of them in the Sierra la Primavera, the other in the Parque de la Liberación, b) undeveloped intraurban and c) the agricultural and control zone.
The highest values of magnetic concentration are observed in land use a) industrial, mixed, urban corridor and b) with primary or secondary roads. The polygon that presented the highest concentration of magnetic particles was the one corresponding to the International Airport "Miguel Hidalgo y Costilla" and its surroundings, as well as the polygon where the Military Air Base is located and extensive areas of entry or exit of the city, as well as Av. Lázaro Cárdenas which crosses the city from Southeast to Northwest, and in a good part of the city is accompanied by the railroad, on which a great variety of substances and materials such as food, machinery, agrochemicals, products are transported. automotive, cement, industrial products, mineral coal, coke, asphalt, paraffin, diesel, fuel oil, iron ore, copper concentrates, silica sand, clays, fluorite and chemical products, among many others (Peña et al., 2016; Peña-García et al., 2019c).

Of the 12 samples (12 individuals) of lung tissue observed in the IJCF, 19 elements were identified in two individuals, 10 in two, three presented nine elements, two more had eight elements and in three more individuals between seven and five elements were observed. The most abundant elements were Al, $\mathrm{Pb}, \mathrm{As}, \mathrm{Hg}$ and $\mathrm{W}$. The least abundant were $\mathrm{Zn}$, $\mathrm{Ta}, \mathrm{Nb}, \mathrm{Hf}, \mathrm{Cu}$ and $\mathrm{Rh}$ (Peña-García et al., 2019a; Peña García et al., 2019c).

\section{Thanks}

This project received support from PROMEP, in the macro of the Networks project "Application of macro and micro-scale numerical modeling for the diagnosis and prediction of the transport and dispersion of pollutants in cities with high pollution indices." The network was titled: Environmental Impact Studies, and was promoted by the Academic Body UDG-CA-423 Applied Environmental Geosciences of the Universidad de Guadalajara.

To Dr. Víctor Rentería Tápia (director), A las doctoras Rocío Castañeda, María Luisa Ojeda, Alejandra Carreón and Dr. Enrique Barrera. 
To Carlos Daniel Barba Rodríguez, Martha Claudia Gutiérrez Jiménez, Dr. Mario Rivas Souza, J. Jesús Francisco Durán Juárez and Angélica Ceceña from the Instituto Jalisciense de Ciencias Forenses (RENIECYT 2016/23661) for having collaborated with the $\mathrm{PhD}$ in Physical Mathematical Sciences of the Universidad de Guadalajara and for the facilities for the observation of lung samples.

Very especially to Dr. Alfredo Ignacio Feria y Velasco ( $\dagger$ ) (Emeritus National Researcher, CUCBA), for his invaluable support.

University of Environmental Geophysics to the Doctors Francisco Bautista, María del Carmen Delgado-Carranza, Rubén CejudoRuíz, Alexander Sánchez-Duque, Juan Julio Morales-Contreras and Avto Gogichaishvili.

And with gratitude and affection to Dr. Javier García Velasco for his permanent support and accompaniment throughout the entire process.

\section{Conclusions}

The diversity of techniques used for the analysis of the samples allowed us to first observe, then identify and finally corroborate the presence of metallic elements in the samples. The SEM technique gave us the facility to observe the shape, size and composition of the particles. By means of XRF, the presence of 21 elements was determined, one non-metal $\mathrm{Br}$ and two radioactive elements Ac and Th.

The areas with the highest amount of dust were the Guadalajara International Airport "Miguel Hidalgo y Costilla", the junction between the highway to Chapala and the Manuel Gómez Morín peripheral ring in the municipality of Tlaquepaque, as well as the extension of Av. López Mateos in the municipality of Tlajomulco de Zúñiga, and the area of the XV military zone, north of the city. It is important to note that in the surroundings of the GMA there are a large number of brick kilns, 831 which burn any kind of waste to supply the kilns.
Atomic absorption spectroscopy allowed the identification of concentrations of the most abundant, $\mathrm{Cu}$ and $\mathrm{Pb}$. In $\mathrm{Cd}, \mathrm{Pb}$ and $\mathrm{Zn}$ are very evenly distributed on Lázaro Cárdenas avenue until reaching the Mercado de Abastos area. The concentration values of $\mathrm{Cd}, \mathrm{Co}, \mathrm{Cr}, \mathrm{Cu}, \mathrm{Ni}$ and $\mathrm{Pb}$ deposited on leaves, exceeded the reference values.

The high concentration of heavy metals found shows that the quality of the ambient air in the GMA is unhealthy, so it would be expected that there would be a correlation between this aspect and the health of the population that resides here. It is important to highlight that the diameter of the particles present in the Ficus benjamina leaves are fundamentally less than 2.5 microns $\left(\mathrm{PM}_{2.5}\right)$ and aggregate states, and that the health problems of the GMA population are associated with fine PM.

In the lung, 21 elements were identified, in addition to observing the shape and size of the particles. Said images were compared with some other environmental particles presented by various authors. Some of the uses of these elements are used in the automotive, electrical and medical industries, in addition to the food industry where they also have great influence. The dust samples collected in this way represent the air that exists at the level that is breathable by the population.

\section{References}

Aguilar, Bertha, Francisco Bautista, Avto Goguitchaichvili, and Ofelia Morton. 2011. "Magnetic Monitoring of Top Soils of Merida (Southern Mexico)." Studia Geophysica et Geodaetica 55: 377-88. https://doi.org/10.1007/s11200-011-0021-6

Aguilar, Bertha, Rubén Cejudo, Juan MartínezCruz, Francisco Bautista, Avto Goguitchaichvili, Claire Carvallo, and Juan Morales. 2012. "Ficus Benjamina Leaves as Indicator of Atmospheric Pollution: A Reconaissance Study." Studia Geophysica et Geodaetica 56: 879-87. https://doi.org/10.1007/s11200-011-0265-1 
Aguilar, Bertha, Victoria Mejía, Avto Goguitchaichvili, Jaime Escobar, Germán Bayona, Francisco Bautista, Juan Morales, and Thomas Ihl. 2013. "Reconnaissance Environmental Magnetic Study of Urban Soils, Dust and Leaves from Bogotá, Colombia." Studia Geophysica et Geodaetica 57: 741-54. https://doi.org/10.1007/s11200-012-0682-9

Air Now, United States Enviromental Protection Agency. 2015. "Understanding Particle Pollution." https://airnow.gov/index.cfm?action=aqibasics. particle

Air Now, United States Enviromental Protection Agency 2016. "Particulate Matter (PM) Pollution." https://www.epa.gov/pmpollution

Bautista, Francisco, José Luis Palacio, Hugo Delfín, Rosaura Pérez, Estela Carmona, and María del Carmen Delgado. 2011. Técnicas de muestreo para manejadores de recursos naturales.

http://www.ciga.unam.mx/publicaciones/image s/abook_file/tmuestreo.pdf

Bautista, F., Cejudo-Ruiz, R., Aguilar-Reyes, B., \& Gogichaishvili, A. (2014). El potencial del magnetismo en la clasificación de suelos: una revisión. Boletín de la Sociedad Geológica Mexicana, 66(2), 365-376.

Cejudo-Ruiz, Lirio, J. M., Chaparro, M. A. E., Gogorza, C. S., Yermolin, E., Silva, A., \& Cuchí Oterino, J. A. (2007). Características sedimentológicas y magnéticas de un depósito cenozoico en una terraza en Cabo Lamb, Isla Vega, Península Antártica. In Actas del VI Simposio Argentino y (Vol. 3, p. 4).

Cejudo, Rubén, Francisco Bautista, and Carmen Delgado. 2013. "Propiedades magnéticas de polvo urbano adsorbido en hojas de Ficus Benjamina y su relación con los metales pesados." Geofisica.Unam.Mx 3: OB4, 1-6. http://www.geofisica.unam.mx/LatinmagLetters /LL13-03-SP/B/OB04.pdf
Cejudo-Ruíz, Rubén, Francisco Bautista, Patricia Quintana, María del Carmen DelgadoCarranza, Daniel Aguilar, Avto Goguitchaichvili, and Juan Julio MoralesContreras. 2015. "Correlación entre elementos potencialmente tóxicos y propiedades magnéticas en suelos de la Ciudad de México para la identificación de sitios contaminados: Definición de umbrales magnéticos." Revista mexicana de Ciencias Geológicas 32 (1): 5061.

Cejudo R., Goguitchaichvili A., Bautista F., Delgado C., Quintana P., Aguilar D., Ramos S., Morales J., Soler A., Cossio_Pérez C., Hernández A., López-Loera H., Caracterización magnética de polvo urbano y plantas de la Zona Metropolitana del Valle de México. Latinmag Letters, 5, (2015), 1-16.

Conny, Joseph M., Sean M. Collins, and Andrew A. Herzing. 2014. "Qualitative Multiplatform Microanalysis of Individual Heterogeneous Atmospheric Particles from High-Volume Air Samples." Analytical Chemistry $86 \quad$ (19): 9709-16. https://doi.org/10.1021/ac5022612

Conny, Joseph M., and Gary A. Norris. 2011. "Scanning Electron Microanalysis and Analytical Challenges of Mapping Elements in Urban Atmospheric Particles." Environmental Science and Technology 45 (17): 7380-86. https://doi.org/10.1021/es2009049

Green, Joanne, and Sergio Sánchez. 2012. "La calidad del aire en América Latina: Una visión panorámica," 36. http://www.cleanairinstitute.org/calidaddelairea mericalatina/cai-report-spanish.pdf

Jia, Jasmine, Sindu Muralikrishnan, Cheng-teng $\mathrm{Ng}$, Lin-Yue Lanry Yung, Boon-Huat Bay, Jasmine Jia'en Li, Sindu Muralikrishnan, Cheng-teng $\mathrm{Ng}$, Lin-Yue Lanry Yung, and Boon-Huat Bay. 2010. "Minireview Nanoparticle-Induced Pulmonary Toxicity." Experimental Biology and Medicine 235 (15353702):

1025-33. https://doi.org/10.1258/ebm.2010.010021 
Maciel Flores, Roberto. 1981. "Geological Mapping in Geothermal Exploration with Special Reference to Tephrochronology and Paleomagnetic Techniques." Iceland. http://www.os.is/gogn/unu-gtp-report/UNUGTP-1981-04.pdf

Maciel Flores, Roberto, and José Rosas Elguera. 1992. "Modelo geológico y evaluación del campo geotérmico La Primavera, Jal., México." Geofísica Internacional 31 (4): 35970. http://biblat.unam.mx/es/revista/geofisicainternacional/43

Marguí, E., Queralt, I., \& Hidalgo, M. (2009). Application of X-ray fluorescence spectrometry to determination and quantitation of metals in vegetal material. TrAC Trends in Analytical Chemistry, 28(3), 362-372.

Miguel, Eduardo De, Juan Llamas, Enrique Chacón, C Fernández, Almudena Ordóñez, A Callaba, s Larssen, and Susan Charlesworth. 2002. "Elementos traza en ambientes urbanos." Boletín Geológico y Minero 113 (1): 35-43. http://www.igme.es/Boletin/2002/113_1_2002/ 6-ARTICULO CARACTERIZACION1.pdf

Muñoz, David, Bertha Aguilar, Raul Fuentealba, and Margarita Préndez. 2017. "Environmental Studies in Two Communes of Santiago de Chile by the Analysis of Magnetic Properties of Particulate Matter Deposited on Leaves of Roadside Trees." Atmospheric Environment 152 (March): 617-27. https://doi.org/10.1016/j.atmosenv.2016.12.047

Oberdorster, Günter, Juraj Ferin, Robert Gelein, Sidney C Soderholm, and Jacob Finkelstein. 1992. "Role of the Alveolar Macrophage in Lung Injury: Studies with Ultrafine Particles." Environmental Health Perspectives 97: 193-99. https://doi.org/10.1289/ehp.9297193

Peña, L., Bautista, F., Cejudo, R., Goguichaisvili, A., Morales, J., Rosas, J., \& Maciel, R. (2016). Distribución espacial de susceptibilidad magnética específica a lo largo de la zona metropolitana de la ciudad de Guadalajara. 6, 1-7. México, D. F., México. Obtenido de https://www.researchgate.net/publication/30610 6997_DISTRIBUCION_ESPACIAL_DE_SUSC EPTIBILIDAD_MAGNETICA_ESPECIFICA_A _LO_LARGO_DE_LA_ZONA_METROPOLIT ANA_DE_LA_CIUDAD_DE_GUADALAJARA
Peña-García, L., Maciel-Flores, R., RosasElguera, J., \& Rentería-Tapia, V. (2016). Distribución de polvo urbano en la zona metropolitana de Guadalajara, México. Revista de Investigación y Desarrollo, 2(4), 16-23. Obtenido de https://docplayer.es/80353868Distribucion-de-polvo-urbano-en-la-zonametropolitana-de-guadalajara-mexico.html

Peña-García, L. E.-F., \& Rosas-Elguera, J. (2017). Presencia de metales pesados en hojas de Ficus benjamina en la zona metropolitana de Guadalajara, México. Revista de Operaciones Tecnológicas, 1(2), 27-32. Obtenido de http://www.ecorfan.org/taiwan/research_journal s/Operaciones_Tecnologicas/vol1num2/Revista _de_Operaciones_Tecnologicas_V1_N2_5.pdf

Peña-García, L., Rentería, V., Maciel-Flores, R., Robles-Murguía, C., \& Rosas-Elguera, J. (2018). Characterization of ambient air dust particulates deposited on Ficus leaves in the Metropolitan Area of Guadalajara, México. ECORFAN Journal Republic of Guatemala, 4(7), 32-41. Obtenido de http://www.ecorfan.org/republicofguatemala/jo urnal/vol4num7/ECORFAN_Journal_Republic _of_Guatemala_V4_N7_3.pdf

Peña-García, L. E.-F., Robles-Murguía, C., \& Rosas-Elguera, J. (2019a). Partículas ambientales en bronquio y tejido pulmonar humano. Revista de Ciencias de la Salud, 6(18), 10-17. Obtenido de https://www.ecorfan.org/bolivia/researchjournal s/Ciencias_de_la_Salud/vol6num18/Revista_Ci encias_de_la_Salud_V6_N18_2.pdf

Peña-García, L. M.-F., Rosas-Elguera, J., \& Robles-Murguía, C. (2019b). Heavy metals present in Ficus benjamina leaves in the metropolitan area of Guadalajara, Mexico. ECORFAN Journal Republic of Guatemala, 5(9), 1-12. Obtenido de http://www.ecorfan.org/republicofguatemala/jo urnal/vol5num9/ECORFAN_Journal_Republic _of_Guatemala_V5_N9_1.pdf 
Peña García, L., \& Rentería, V. (Octubre de 2019c). Partículas ultrafinas ambientales en el área metropolitana de Guadalajara, México. Tesis para obtener el título de doctor en Ciencias Físico matemáticas. Ameca, Jalisco, México: Universidad de Guadalajara. Obtenido de

http://www.docfm.cuvalles.udg.mx/sites/default /files/user/mtau37/22laura_elizabeth_pena_garc ia_tesis_compressed_1.pdf

Perez Fadul, L. F., \& Hernández Hernández, L. (2006). Determinación de metales pesados en partículas respirables e identificación de fuentes de emisión, a partir de un muestreo atmosférico en la localidad de Puente Aranda en la ciudad. https://ciencia.lasalle.edu.co/ing_ambiental_san itaria_/673

Querol, Xavier. 2008. "Calidad del aire, partículas en suspensión y metales." Revista Española de Salud Pública 82 (5): 447-53. https://doi.org/10.1590/S1135-

57272008000500001

Ram, S S, S Majumder, P Chaudhuri, and S Chanda. 2014. "Plant Canopies: Bio-Monitor and Trap for Re-Suspended Dust Particulates Contaminated with Heavy Metals." Mitigation and Adaptation Strategies for Global Change $19 \quad$ (5): 499-508. https://doi.org/10.1007/s11027-012-9445-8

Sánchez-Duque, A., Bautista, F., Goguitchaichvili, A., Cejudo-Ruiz, R., ReyesLópez, J. A., Solís-Domínguez, F. A., \& Morales-Contreras, J. J. (2015). Evaluación de la contaminación ambiental a partir del aumento magnético en polvos urbanos. Caso de estudio en la ciudad de Mexicali, México. Revista mexicana de ciencias geológicas, 32(3), 501-513.

Sangi, M. R., Shahmoradi, A., Zolgharnein, J., Azimi, G. H., \& Ghorbandoost, M. (2008). Removal and recovery of heavy metals from aqueous solution using Ulmus carpinifolia and Fraxinus excelsior tree leaves. Journal of hazardous materials, 155(3), 513-522.

Sawidis, T., Marnasidis, A., Zachariadis, G., \& Stratis, J. (1995). A study of air pollution with heavy metals in Thessaloniki city (Greece) using trees as biological indicators. Archives of Environmental Contamination and Toxicology, 28(1), 118-124.
Tam, N. F. Y., Wong, Y. S., \& Wong, M. H. (1988). Heavy metal contamination by Alfabrication plants in Hong Kong. Environment international, 14(6), 485-494.

Tomašević, M., Z. Vukmirović, S. Rajšić, M. Tasić, and B. Stevanović. 2005. "Characterization of Trace Metal Particles Deposited on Some Deciduous Tree Leaves in an Urban Area." Chemosphere 61 (6): 753-60. https://doi.org/10.1016/J.CHEMOSPHERE.200 5.03.077 